\title{
The proposal for the development of a non- formal education activities model for teachers in foundations for disadvantaged children
}

\author{
Siriporn Jinanarong ${ }^{\text {la }}$, Suwithida CharungKaittikul ${ }^{1}$, and Rangsiphan Khaengkhan ${ }^{1}$ \\ ${ }^{1}$ Chulalongkorn University, 254 Phayathai Rd., Pathumwan, Bangkok 10330 Thailand
}

\begin{abstract}
The dramatic increase in the numbers of disadvantaged children (or under privileged children) in the past few years has become a considerable concern for Thailand. Educators are worried about the quality of these children's education. The demand for quality educators has increased for these children. This paper describes a newly developed model for teacher's education. It targets the teachers who teach disadvantaged children in the foundations. The objective of the research step is to expose the children to aesthetic experience by using experiential learning and brain based learning. The target group is pre-school children who are under the care of foundations in Bangkok metropolitan areas.
\end{abstract}

Keywords: disadvantaged children; teacher's education; education model.

\section{Introduction}

The dramatic increase in the numbers of disadvantaged children in the past few years has become a considerable concern for Thailand. Educators are concerned about the quality of these children's education. The demand for quality educators has increased. There is neither adequate numbers of teachers nor qualified teachers for this type of learners. There are several types of disadvantaged children and each of the types requires different care and special learning to address their problems. In 1999, an act of legislation announced the 11 types of disadvantaged children as: homeless children, stateless children, children of foreign workforce, children with HIV, orphan, under-aged labour, Under-aged prostitution, drug addicted children, children with family in poverty, children live in rural area, and autistic children. Each type of disadvantaged children has different needs to ordinary children and requires specialist teachers [8].

\footnotetext{
a Corresponding author: sjinanar@hotmail.com
} 


\subsection{Statistics}

From statistics, the number of disadvantaged children has been increasing over the past 10 years. In 2005 the percentage of disadvantaged children in school was $32.11 \%$. The number has been increased to $58.43 \%$ in 2012 . Studies found that these disadvantaged children have problems with development, personality, and health. Detail of the types and the estimated number of disadvantaged children in 2014 is in Table1 [7].

Table1. Types and estimated number of disadvantaged children in Thailand

\begin{tabular}{lrl}
\hline Category & $\begin{array}{l}\text { Estimated } \\
\text { Number } \\
\text { person) }\end{array}$ & Special Needs \\
\hline Homeless children & 30,000 & Long term life skill and education \\
Stateless children & $200,000-$ & Health care, education, nationality \\
Children of foreign & 300,000 & \\
workforce & 25,000 & Special education and cultural acceptance \\
Children with HIV & 50,000 & Health care and social acceptance \\
Orphan & 88,730 & Love and care, education \\
Under-aged labor & 10,000 & Work, education, psychological and health care \\
Under-aged prostitution & 25,000 & Work, education, psychological, health care, and \\
social acceptance \\
Drug addicted children & 10,000 & $\begin{array}{l}\text { Work, education, psychological, health care, and } \\
\text { social acceptance }\end{array}$ \\
Children with family in & $2,978,770$ & Special education \\
poverty & 160,000 & Education opportunity \\
Children live in rural area & $2,500,000$ & Special education according to the type of autism \\
Autistic children &
\end{tabular}

\subsection{Cause of the problem}

The cause of the increasing numbers may be changes in the society. Families are weakening without support of the extended family. There has been a report of fewer marriages and more divorces over the past 20 years. Poor parents may be busy at work, or may have to work away from home. As a result, children have been taken care of by the grand parents or relatives instead of the parents. Some of the children have to stay by themselves without adult care. In addition, the effect of globalization creates a materialistic society. People need more money to purchase expensive items in order to be accepted in society. If the family does not have enough money, unsecured loans outside of the systems may be used as a source of funding. As a result, families are in debt. Lastly, the inadequate social welfare deepens these children's problems [5].

\subsection{Projects for disadvantaged children}

Projects have been created to enhance the quality of life for different groups of disadvantaged children by both government and non-government organizations. Each of the project targets to the special needs of the different groups. Example of these projects includes: project to help children with learning disorders, schools for children live in rural 
area, special schools for stateless and foreign workforce children, and special schools for under-aged mother. However, the help is still not adequate. More projects for each special need are still in demand. The improvement of these children's education is still needed. Qualified teachers are still in demand. This paper is another special project targeted at enhancing the skills of teachers who teach orphans or children who have been abused.

\section{Method}

\subsection{Research objectives}

The main objective of this research is to develop a non-formal education activities model for teachers in foundations. The activities are targeted orphans or children who have been abused which is one of a specialized group in the category of disadvantaged children in Thailand. The project consists of 3 phrases: (1) to analyze the existing situation, conduct a needs assessment and to identify the characteristics of the teachers who teach disadvantaged children in the foundations (2) to develop a non-formal education activities model for children and train the teachers who teach disadvantaged children in the foundations; (3) to suggest a policy of experiential teaching and learning activities for Thai foundations.

\subsection{Research concepts}

To create a new activities model, combining 3 concepts: brain based learning [4], experiential learning theory and learning style [6], and aesthetic experience [1]. The brain based learning is a scientific study of brain development in relation to education. The understanding of brain development in young children is believed to be related to children's behaviour. The teacher's understanding of child's brain development is an ideal for educators. The Caine's brain/mind principles of natural learning were chosen for this research because of their clarity and adaptable for the target group. The principles consists of: (1) all learning is physiological (2) the brain/mind is social (3) the search for meaning is innate (4) the search for meaning occurs through "patterning" (5) emotions are critical to patterning (6) the brain/min processes parts and wholes simultaneously (7) learning involves both focused attention and peripheral perception (8) learning always involves conscious and unconscious processes (9) there are at least two approaches to memory; archiving isolated facts and skills or making sense of experience (10) learning is developmental (11) complex learning is enhanced by challenge and inhibited by threat associated with helplessness (12) each brain is uniquely organized [3]. The experiential learning cycle can be described in 4 stages: concrete experience (doing/having an experience), reflective observation (reviewing/reflecting on the experience), abstract conceptualisation (concluding/learning from the experience), and active experimentation (planning/trying out what you have learned). The third teaching concept is aesthetics and aesthetic experience which cannot be taught as separate specific subjects. But it can be taught as an integral part of different classes, usually art or music.

\subsection{Research method}

In this research, both qualitative and quantitative methods are used. Each of the phases required different methods. For the first phase, data gathering is involved. The research method includes: need assessment, document analysis, site visits, administrators interviews, 
teacher questionnaires and the discussion with experts. For the second phase of the project: actual teaching will be performed at selected location. The teachers will be trained at the same time as the children. This 'on the job training' will save time for teachers who do not leave the classroom for special teacher training. Another advantage is the teaching will be adapted to the special group that will be being tested at the site. Third phase is the conclusion of the entire project. A focus group of experts will be formed to develop suggested policy for this group of disadvantaged children.

\subsection{Data collection tools}

For each phase of the research, both qualitative and quantitative tools will be employed according to the research methods. During the first phase data will be collected from multiple foundations as a needs assessment of teacher training. Once data has been collected and analyzed the output of this first phase will be the input for the second phase. During the second phase, the actual teaching will occur at one of the selected foundation in the Bangkok area. The tools related to this phase are: teaching plans, pre and post test questions for the teachers in the foundation, observation and video analysis. The children's evaluation will be analysis teacher's daily assessments. Following analysis, the data from the second phase will be used as part of the input for the third phase. Lastly, focus group questions will be created to confirm and suggest policy ideas for the development of a nonformal education activities model for teachers in foundations for disadvantaged children.

Table 2. List of tools required for the research project

\begin{tabular}{llll}
\hline Tools & Target & Type & Phase \\
\hline Foundation administrators interview & Foundation administrators & Qualitative & 1 \\
Foundation's teachers questionnaire & Foundation's teachers & Quantitative & 1 \\
Teaching plan & Foundation's teachers and children & Qualitative & 2 \\
Pre-tests questionnaire & Foundation's teachers & Quantitative & 2 \\
Post-test questionnaire & Foundation's teachers & Quantitative & 2 \\
Observation form & Teachers and children & Qualitative & 2 \\
Children's evaluation & Children & Qualitative & 2 \\
Focus group questions & Related experts & Qualitative & 3 \\
\hline
\end{tabular}

\section{Results and discussion}

At this stage, document analysis, site visits, and consultation with experts have been completed. From document analysis and site visits, the researcher found that this type of child requires consistent love and care more than is needed for ordinary children. Lack of parenting or abusive parenting problems may cause long term behavior issues. Some of the unwanted behaviors can be observed when the children are young. Moreover, the foundation's administrators suspect that the effect of the unwanted behavior may be long term and cause problems in teenager years. There is no permanent cure for this psychological damage for children without parents. The damage from lack of parents or abusive parents remains for the rest of their child life. For these juveniles there is no way to replace their real parents.

The planned activities model can be described as follows. Movements and music activities are the focus. Questions, such as like or dislike and why, are planned to be asked at the end of each activity [2]. These questions expose learners to aesthetic experiences. The group activities are positive and repeated with variations and lots of explorations. The group 
activities improve learner's social skills. Learners will search for meaning of activities by the pattern of similar activities and questions. They are expected to improve learner's emotion and learning development in both consciousness and unconsciousness. With the repeated pattern of activities over time, the learners will be encouraged to try new things from what they have learnt or observed. Learners will have chances to watch the others, think for their own actions, show the other their own creations, and thought and feel (like or dislike) on the other activities.

The teachers in foundations are expected to be able to lead movement and music as part of their learning. In addition, they should be able to create new activities, which should be more suitable for the foundations they are working with. The researcher hope that sets of activities will improve children's behavior. Through patterns and repetitions, the positive changes in the children brain development occurs. It is hope that the created activities model will improve the children's life. The researcher hopes that the developed activities model will help the child learn, accept the situation, adapt, help and support each other. It is hope that they will grow up healthy physically and mentally with the help at the foundation.

\section{Conclusion}

The search for a long term solution for these underprivileged children is ongoing. The next step of the research will be the analysis of the first phase data which will lead to the activities plan, test, evaluate, and develop at a selected foundation. The test location will be at the Foundation for Children located in the outskirt of Bangkok. Actual activities will be conducted for both teachers and children at the same time. The researcher believes that the newly developed activities model will should support on disadvantaged children in becoming citizens who can make a positive contribution to society.

\section{References}

1. Beardsley, M. C., \& Schueller, H. M. Aesthetic Inquiry: Essay on art criticism and the philosophy of art. Belmont, CA: Dickenson Publishing Company., (1967).

2. Bhromoon, $\mathrm{P}$. การพัฒนาโรงเรียนเข้าสู่มาตรฐานการศึกษา สุนทรียภาพทางศิลปวัฒนธรรม. Bangkok: Office Education Quality., (1996).

3. Caine, G., \& Caine, R. The Caines' Brain/Mind Principles of Natural Learning. Retrieved June 25, 2015, from Caine Learning: A home for natural learing and deep. (2015). listening: http://www.cainelearning.com/brain-mind-principles/

4. Caine, G., \& Caine, R. N. Making Connections: Teaching and the Human Brain. New York: Addison-Wesley Longman., (1994).

5. Faculty of Social Administration Thammasart University. รายงานสถานการณ์เด็กยากจนตามโครงการ การจัดทำแผนยุทธศาสตร์การแก้ไขปัญหาเด็กยากจนและเด็กด้อยโอกาส 3 ปี (25492551) . Bangkok: Thammasart University., (2006-2008)

6. Kolb, D. Experiential Learning: experience as the source of learning and development., (1984). Englewood Cliffs , NJ: Prentice Hall.

7. Quality Learning Foundation. เอกสารประกอบการประชุมวิชาการ "อภิวัฒน์การเรียนรู้..สู่จุดเปลี่ยนประเทศไทย". Bangkok: Quality Learning Foundation (QLF)., (2014).

8. Royal Thai Government Gazette. Thailand National Education Act. Bangkok: Royal Thai Government., (1999). 